\title{
Young people's higher education choices: the role of family and friends
}

\section{Rachel Brooks}

Published in the British Journal of Sociology of Education, 2003

\begin{abstract}
Previous studies of higher education (HE) choice have tended to draw a strong contrast between the decisions made by young people from working class backgrounds and those of their middle class peers. This paper draws on a qualitative, longitudinal study to argue that such assumptions about social class homogeneity overlook the very different ways in which students from a similar (middle class) location come to understand the HE sector. It also suggests that while families have a strong influence on young people's conceptualisation of the sector, friends and peers play an important role in informing decisions about what constitutes a 'feasible' choice. Indeed, this paper shows how rankings within friendship groups were, in many cases, transposed directly onto a hierarchy of HE institutions and courses. On the basis of this evidence, it concludes that a two-step interaction between family and friends best explains the decisionmaking processes in which these young people were engaged.
\end{abstract}




\section{Young people's higher education choices: the role of family and friends}

\section{Introduction}

Recent research on young people's HE choices has paid close attention to familial influences and has provided compelling evidence that class positions have a strong bearing on both how young people understand the HE market (Ball et al., 2002; Pugsley, 1998; Reay et al., 2001b), and their decisions about whether or not to go on to university or college (Archer and Hutchings, 2000; Walkerdine et al., 2001). This paper attempts to extend this understanding by focussing on two themes that are neglected by these otherwise wide-ranging analyses. First, it suggests that the heterogeneity of the middle classes has been overlooked within many of these accounts. Indeed, when exploring the choices of those from a middle class background, these studies have generally focussed on the upper or professional middle classes and/or young people with considerable family experience of higher education. The research discussed in this paper focuses more specifically on what Gershuny (1994) call the 'liminal' middle classes, and maintains that a sociological understanding of the decision-making process of the lower middle classes is also important in developing a more nuanced account of how young people think about their futures. Second, this paper argues that the influence of friends has been undertheorised within previous work on HE choice. Several studies have certainly alluded to the role played by friends and peers (David et al., 2001; Reay, 1998; Reay et al., 2001a), but the precise nature of the influence has not been explored. This paper attempts to illuminate some of these processes and the ways in which family and friend influences may interact.

The paper is based on a two-year case study of the experiences of fifteen young people between the ages of 16 and 18 at 'Emily Davies College' (a pseudonym), a sixth-form college in the south of England. Each term, between September 1999 and September 2001, individual, indepth interviews were held with the young people and covered their experiences at college, plans for the future, and thoughts and decisions about applying for higher education courses. Emily Davies College is a large institution, with around 900 students in each year group and, typically, around 70 per cent of each cohort go on to gain a place at a higher education institution. The young people who took part in this research generally obtained GCSE and A Level results higher than the college average, but did encompass a reasonably wide spectrum of attainment ${ }^{1}$. In common with most of the other students at Emily Davies College, they had attended local state secondary schools and came from broadly lower middle class families with little prior experience of higher education (see Table I).

[insert Table I]

\section{Conceptualising the HE market}

\section{Institutional hierarchies}

Several empirical studies of higher education choice have demonstrated the distinctions between institutions that are made by both students and employers. These distinctions have been interpreted largely as a result of the mass expansion of the sector and the supposed need for the middle classes to find new ways of ensuring the reproduction of their class advantage (Ainley,

\footnotetext{
${ }^{1}$ The A level point scores of the young people in the sample ranged from 38 (Becky) to 2 (Rich).
} 
1994; Brown and Scase, 1994). However, although the young people involved in this study were from broadly similar social backgrounds, they differed considerably in their knowledge of and engagement with the higher education market; not all the young people constructed identical types of hierarchy, nor did they attach the same importance to attending a 'highly ranked' institution. On the basis of these differences it is possible to identify four main approaches to issues of institutional status and reputation.

Four young people (Becky, Paul, Simon and Steve) constructed a detailed and conventional 'league table' hierarchy. These students not only favoured 'old' universities over 'new', but were also aware of more subtle distinctions in reputation between the institutions in the two categories. Although not all four students had actually made use of published league tables, several were acutely aware of the relative positions of the different institutions and were able to quote the places of particular HEIs during interviews. The young people in this group had typically been aware of differences within the HE market at the time of their first interview and all attached great importance to attending a 'high status' university. Indeed, Steve was even prepared to choose a course he was less keen on if it meant he could get into a prestigious university.

A second group (Jim, Liz and Sunita) was aware of status differences between institutions but differed from the young people discussed above in their relative lack of confidence at 'reading' the market. For example, throughout her two years at Emily Davies College, Sunita had emphasised the importance of securing a place at a 'top 30' institution:

Sunita: $\quad$ I think the first 30 are OK. Below that it's a bit pointless actually. RB: $\quad$ Why do you say that?

Sunita: $\quad$ Because if you get really low grades at A Level it's silly going to university - because you got low grades you go to a low university and get a low degree so you might as well do something else: some training or a work placement somewhere. (Interview 3)

However, her knowledge of the relative status of HEIs was based solely upon university league tables published in newspapers. She talked about the difficulty of interpreting this information when certain places (like Swansea, where she eventually secured a place) appeared in the top 30 in some tables but in lower positions in others. This was particularly apparent during the last interview when she described her difficulty about deciding which institutions to contact during clearing:

...You see it in league tables in the newspaper - it was like 44 in one of them and I was like 'Is this right or not?' I was feeling a bit kind of like let down and then I looked at another one and it was in the top 30. They go up and down and you feel like, 'Have I gone to a high university or [not]?' ... 'Which one is right?' You can't trust them. (Interview 6)

Her obvious confusion and lack of confidence at reading the market contrasts markedly with her more assured peers, discussed above, none of whom ever spoke about any ambiguity in an institution's status.

A third group of students (Clare and Lucy) also ranked institutions in a hierarchical way but, for them, their judgements were based on a range of 'vocational' considerations such as the advertised rate of graduate employment and links with local employers. The language these 
young people used to differentiate between HEIs reflected this perspective, often contrasting 'academic' universities unfavourably with their 'vocational' counterparts. Clare and Lucy differed from the 'league tablers' in several other important respects. First, the hierarchies of HEIs that they constructed were much more geographically limited than those of the young people discussed above. They were aware of the differences in reputations of local HEIs but claimed they had little idea of the relative status of universities outside of the south of England. Second, in contrast to many of their peers, Clare and Lucy knew relatively little about the higher education system generally at the time of the first interview.

Finally, four young people (Charlotte, Mark, Sarah and Zoë) claimed that they were unaware of the relative status of HEIs. In Sarah's case this was because she had made a conscious decision not to find out about such differences. She was aware that not all universities had the same reputation but maintained that her past experiences of choosing a secondary school and sixthform college had taught her to disregard reputation. Zoë and Charlotte both claimed that they were not aware of any differences in the status of universities and colleges - at least until after they had sent off their UCAS forms. They were not unaware of all hierarchies, however. Both seemed to have substituted a subject-based hierarchy for one that was institutionally-focused: they had applied for high status courses (medicine and law) and during the interviews emphasised the status of their planned career rather than the place at which they would study.

\section{Subject hierarchies}

While much of the literature about HE choice has focussed on perceptions of institutional status (Ainley, 1994; Brown and Scase, 1994; Reay et al., 2001b), relatively little has been written about the way in which hierarchies of degree subjects are constructed or the ways in which such hierarchies intersect with perceptions of institutional status. However, the research at Emily Davies College suggests that the status that young people assigned to particular subject areas affected not only their own choice of subject, but also the institutions to which they applied. In some cases, at least, the young people engaged in an intricate balancing act in an attempt to maximise the status of both institution and subject.

Although Zoë and Charlotte were relatively unaware of the reputation of HEIs (at least until after they had applied), the status of subjects was of great importance to them and they both had developed a detailed hierarchy of degree subjects. Charlotte explained that: 'I guess I kind of went for something that... almost people expect you to do if you get good grades - it's either that [law] or medicine' (Interview 6). Paul and Steve, both of whom ranked law particularly highly, also shared such views. For these young people, the high status that they attached to these courses was in part derived from the status of the careers with which they are associated. This was not necessarily the case for all the young people, however: for some, status seemed to be related to the perceived difficulty of the course or the extent to which it was seen to be 'vocational' or applied. Simon valued courses such as history and politics above more applied ones, because he felt they provided a 'better all-round education' and kept his career options open, while for Clare, Lucy and Sunita, the highest status courses were those that were most closely tied to a particular employment sector, offered work experience or placements, and had high rates of graduate employment.

The methods by which the young people ranked courses had much in common with their hierarchical categorisation of higher education institutions. Nevertheless, the way in which these various subject hierarchies intersected with considerations of university status differed amongst the young people. Some prioritised the hierarchy of courses over that of institutions; others were more concerned to ensure that they went to the highest status institution possible; 
and, while Steve compromised on his choice of course (choosing East European studies instead of law) to ensure that he could get into a 'higher status' university, the status of both remained important to him.

\section{Explaining the hierarchies}

The evidence from the Emily Davies students suggests that the young people's parents and stepparents played a pivotal role in informing their attitudes to higher education. In very few cases were there any obvious disparities between a young person's perception of, for example, the purpose of HE or a particular institution or course, and what they reported of their parents' views. In terms of conventional indicators of social class, it is hard to find any significant differences between most of the young people who took part of the research (with the exception of Liz and Lucy): they had attended similar secondary schools and lived in similar types of housing. Moreover, their parents and/or step-parents were employed in similar types of job and few had been to university themselves. However, there were considerable differences in the extent to which families were involved in the decision-making process and in their knowledge about HE, generally, and the relative status of institutions and subjects, more specifically.

It is possible that a more detailed comparison between the families of the young people may help to explain some of the differences. Although the classification of parental occupations in terms of the Registrar-General's categories did not differ greatly, a finer-grained analysis of the contexts in which the young people's parents worked provides a possible explanation of why some parents were sensitive to institutional and subject status and others were not. For example, the fathers of Simon and Steve both came into contact with colleagues who had been to university and, as a result, had come to believe that not all institutions carried equal value in the workplace:

Steve: $\quad$ My dad tells me about people at work. Cos he's like half way up, but at [oil refinery company] all the top brass are like from Oxford and he reckons people from Oxford run the show and they kind of set out what they think they should be, and then people from lesser universities actually work out how to do it, and then people who haven't been to university actually have to do it. (Interview 6)

RB: $\quad$ So where do you think he [father] has got his information about the importance of reputation from?

Simon: $\quad$ Probably from work and stuff. He says all these upstarts are always coming in and taking people's jobs.

RB: $\quad$ Does he have a role in choosing graduates?

Simon: $\quad$ Yeah. Well, he employs them and sacks them. (Interview 4)

This distinguished them from the parents of other young people in the sample, whose workplaces had not provided them with similar opportunities for gauging the status attached to particular HE courses and institutions. For example, Mark was located in the same social class (II) as Simon and Steve - but claimed that his parents had no desire for him to apply to any particular institution. His mother was a teacher at a primary school and his father was a salesman and, from Mark's accounts, it seems that neither parent had had much exposure to conversations about HE within their place of work. This suggests that a similar social class classification may mask considerable disparities between parents in their first-hand knowledge of the nature and impact of higher education hierarchies. 
A second possible explanation for the differences between the young people may lie in their previous educational experiences and, in particular, the extent to which they had identified themselves as 'high achievers' (or been identified as such by others) at an early age. The families of both Becky and Zoë had a clear sense of higher education hierarchies - in Becky's case, in terms of institutional status and, in Zoë's, in terms of the status attached to specific degree subjects. However, neither sets of parents had been to university themselves, and neither Becky nor Zoë mentioned that their parents had gained their views about hierarchies from the workplace. Instead, their narratives suggest that, as Becky and Zoë had both been certain that they would go on to university from a young age (and their teachers at school had confirmed this likely destination), their parents had had both the time and motivation to find out more about the higher education sector and what a 'high achiever' could hope to achieve. For example, Zoë described how her teachers had informed her and her parents of what she would have to do to maximise her chances of getting into medical school (such as gaining relevant work experience and shadowing doctors) when she was choosing her options at school. It appeared that her parents had then assumed responsibility for these extra-curricular activities: 'They gave me a nudge and said, "You've got to get on with this"" (Interview 2).

There may well be further explanations that help to explain the differences in knowledge of, and attitude to, higher education hierarchies between the families of the young people involved in this research. However, the two suggestions above go some way to deconstructing what is often assumed to be the homogeneity of the middle class. For example, Walkerdine et al. (2001) argue that the transition to HE is qualitatively different for young women from working class families and their middle class peers. They claim that for the middle classes: "what is aimed at by children is becoming like their parents in the sense of having the same kind of career as them, the same levels of income, material comfort and lifestyle', while 'for working class daughters the message is quite different; it is clearly about not becoming like them and it is this which is central both to the daughters' drive towards higher education and to the deep ambivalences that beset some of them concerning the same' (p.158). The evidence from the Emily Davies students would suggest, however, that this is an over-simplification of highly complex class differences. The narratives of the largely lower middle class students in this research do not resonate with Walkerdine et al.'s description of middle class assumptions and motivations. Far from wanting to emulate their parents, most of the young people at Emily Davies College "wanted something different' - articulated particularly clearly by many of the young women when talking about their mothers:

Charlotte: At the moment she [mother] is a secretary in a school. She did a typing course and worked abroad but she didn't go on to university.....I definitely don't want to do what my mum does. (Interview 2)

Zoë: $\quad$ My mum was very pressured into what she wanted to do. They were like, my grandparents, 'You have to be a secretary' - so that's what she did. (Interview 2)

Becky: $\quad$ I mean she was a really bright student at school herself but she never did that well in the end in their Year 11s [O Levels]. And she never went on any further because she couldn't do it. So now that I can go somewhere she really wants me to go as far as I can. I think that's what it is. (Interview 4)

Furthermore, the 'feelings of guilt' which Walkerdine et al. discuss in relation to the HE choices 
of working class young women were equally evident amongst the young women (and some of the young men) at Emily Davies College. This suggests that the process of HE choice amongst the middle class is more complex and highly differentiated than Walkerdine et al. claim and that the experience of some young people from lower middle class backgrounds, with no family history of HE, may have more in common with the working class young people in Walkerdine et al.'s sample than with other fractions of the middle class. Their assertion that: 'middle class children receive the message from birth that not only are they able and clever, but also that their destiny is to go to university and become professionals' (p.162) is consonant with the experiences of only one or two of the Emily Davies students.

\section{The heterogeneity of the middle classes}

Various studies of educational choice (Gewirtz et al., 1995; Lauder and Hughes, 1999; Reay, 1998) have outlined what have been called the 'class strategies' of middle class parents: attempts 'to achieve a class fit between the habitus of home and institution and avoid social mixing' (Ball and Vincent, 2001, p.186). Implicit in these studies seems to be an assumption of a unitary and homogenous middle class, defined primarily in terms of its difference from the working class. Indeed, Savage (1995) has noted that, as a result of a strong tendency to conflate class in general with the working class in particular, the construction of middle class identities has primarily been related to the claim that one is 'not working class'. Such assumptions pervade much of the educational literature, but have also been clearly articulated within some studies of social mobility. Goldthorpe $(1982,1995)$, for example, has developed the concept of the 'service class': a class that comprises the more powerful members of the middle class, typically managers and professionals, and that grew rapidly over the course of the twentieth century. Members of this class are differentiated from other workers by differences in the nature of their conditions of employment. Goldthorpe argues that, within the service class, and in contrast to other workers, the relationship between employer and employee is based on a high level of trust. He contends that: 'how well these employees perform....will in crucial respects depend on the degree of their moral commitment to the organisation, rather than on the efficacy of "external" sanctions and rewards' (1982, p.168). The homogeneity of the service class is also emphasised. Indeed, it is a logical consequence of the rational action theory that underpins his work (1996, 1998). This holds that decisions - about educational progression, for example - are made on the basis of rational calculations about the costs, benefits and probabilities of various options. Goldthorpe acknowledges that, as different class locations give rise to very different costs and benefits, there is likely to be a high degree of inter-class variation. Nonetheless, within a particular class, it is the probable similarity of the decisions that is stressed.

However, as this section has demonstrated, the research at Emily Davies College highlighted a high degree of intra-class variation. Young people, from very similar social locations, came to understand the structure of the HE market in very different ways and seemed to possess quite diverse 'horizons for action' (Hodkinson et al., 1996). Hatcher (1998) has effectively outlined the considerable variety in the ways in which young people from working class backgrounds made educational choices and approached points of transition; this study suggests that an equal degree of diversity may be apparent within the middle class. In doing so, it reflects the findings of a number of social mobility studies that have contested Goldthorpe's position and, instead, emphasised the fragmentation of the middle class - culturally, economically and spatially. For example, Savage et al. (1992) have argued that are at least three different sections of the middle class (the petit bourgeois, professionals and managers), each relying on different assets in the process of identity formation (property, culture and their place in an organisational hierarchy, respectively). Further, Crompton (1992) has argued that a range of influences will determine the (different) social consciousness of members of the middle class, including their family of origin, 
social background, gender and experience of higher education. Indeed, different 'social consciousness' were evident in this study. This section has shown that parents influenced their children's understanding of the HE market not necessarily on the basis of their achieved class position or their own HE experience, but on the basis of finer-grained differences such as the extent to which they had had contact with graduates within the workplace. Moreover, it has demonstrated considerable differences in the degree to which middle parents acted 'strategically'. While some families drew on their knowledge of the HE market to try to further their social advantage, others, who shared the same social position, were clearly not pursuing any such 'class strategy'. These different familial assumptions and practices had an important bearing on the HE choices the young people made and how they came to 'find their place' in the HE market. These processes are explored further below.

\section{'Finding one's place'}

It was clear from the young people's narratives that their families played a key role in informing their understanding and conceptualisation of the HE market. However, when it came to finding their own place within it and deciding which courses and institutions represented, for them, a feasible choice, familial influence was less evident. Instead, such decisions were informed by the ways in which the young people positioned themselves in relation to their peers within their friendship groups. These positions were, inevitably, influenced to some extent by messages that the young people had received from their families and from the educational institutions they had attended about their own 'ability' and academic standing. Nevertheless, as the following section will demonstrate, in some cases, processes of ranking and comparing between friends appeared to distort these messages. Indeed, for almost all the young people involved in this research, friends and peers were of central importance in locating one's place on the emerging HE hierarchies.

\section{The ranking of friends}

Throughout the two years of the research, it was apparent that almost all of the young people were aware of what they perceived to be their academic standing relative to their friends and peers and, for some, this positioning was of great importance (both for university entry and their own sense of identity). During the interviews, many of the young people described differences between themselves and their friends in terms of their levels of academic attainment. For some, such as Charlotte and Zoë, this awareness came from a constant (and explicit) comparison of grades:
Charlotte: Although we're really good friends, when it comes to a test and stuff, we are quite competitive.
RB: $\quad$ So do you compare your grades and things like that?
Charlotte: Yeah! The minute the grades come through everyone's on the phone, 'What did you get?!' (Interview 2)

Such comparisons, whether explicit or implicit, resulted in a series of 'rankings' in which the young people placed themselves in some kind of hierarchical order, relative to others in their friendship group and wider social networks. The language in which the young people talked about these 'rankings' of friends and peers focused largely on notions of actual academic attainment and typically emphasised: GCSE grades, the results of college tests and modules and/or the grades they had been predicted by teachers for their A Levels. For example, Steve described the differences between his friends in this way: 
I think there's quite a big gulf. There's like Joe and Bhupinder who are pretty much up there; then there's like Ben, Jamie and perhaps me who are in the mid-range band, like Bs and Cs; and then there's probably Mark and Sam and Pete who'd probably be chuffed to bits to get away with three Cs. Yes, it's a pretty wide spectrum.

(Interview 2)

However, despite the meritocratic assumptions that pervade the language used by Steve and most of the other young people involved in the research, it was apparent that the rankings that individuals assigned to themselves and their friends were not always consistent with the grades that the young people reported having attained.

In common with other empirical studies of processes of selection and stratification in schools and colleges (Ball, 1981; Gillborn and Youdell, 2001; Hargreaves, 1967; Troyna, 1991), it appears that perceptions of ability were strongly influenced by other (social) factors. For example, Lucy and Liz compared themselves unfavourably with their friends at several points during the research, and frequently expressed surprise at their exam results. Although the interviews provide no conclusive proof about why Lucy and Liz perceived their academic ability to be lower than many of their friends and peers when the grades that they obtained suggested otherwise, it seems likely that the assumptions and experience of their families may have played a significant role. Both young women described how their family knew very little about the education system and in neither case did their parents or step-parents assume that they would go on to university. Indeed, both felt that their parents/step-parents would be as happy for them to get a job on leaving Emily Davies College as to go on to HE. Indeed, the amount of "cultural capital' (Bourdieu, 1997) on which they were able to draw was considerably less than for many of the other young people in the study - apparently explained by Liz's SES background and the low level of educational qualification obtained by Lucy's parents (see Table I).

It appeared that judgements about the amount of effort put into academic work also distorted the supposed relationship between ranking relative to peers and attainment. In several cases, the ranking of high attaining individuals seemed to be lowered a little by a recognition that they worked extremely hard to achieve their results.

Steve: Joe's been the kind of...I wouldn't say he's more intelligent, I think he's got more of a work ethic than me and Ben. (Interview 4)

While for others, an assumption of 'natural ability' augmented the rank that others assigned to them:

Zoë: $\quad$ I think Rose and Amy going to Oxford to do chemistry is perfect because they are both so clever and I think they will fit Oxford....I think they'll do really well there because they tend to sort of, they do the work and get it done. They do it the first time and get it the first time. (Interview 6)

The relationship between academic attainment and rank relative to peers was further distorted, in some cases, by the very process of making constant comparisons with others (see also, Walkerdine et al., 2001). In Charlotte and Zoë's friendship group, for example, the difference in grades obtained by Charlotte, Zoë and their friend Sinead was small. However, throughout the two years, because of the highly competitive nature of the group and the way in which the young women constantly compared their results, Charlotte was acutely aware that Zoë was achieving 
slightly higher grades than she was. Thus, although Charlotte continued to define herself as a 'high achiever' during her time at college, the constant competition between the friends had the effect of rendering Charlotte's performance, which was very high compared to attainment levels across the college as a whole, as quite ordinary. For these young women, grades had serious consequences for their self-perception and level of confidence and, in common with the findings of several other studies (Becker et al., 1968; Hinett, 2002; James, 2001), assessment results were frequently elevated to the 'point where they appear as naturalized personal knowledge' (James, ibid., p.164). In these ways, friends played an important role in constructing an individual's sense of 'ability' and position relative to peers. Although these influences were invariably exerted subtly and were rarely recognised by the young people themselves, they had a considerable impact on decisions made about higher education.

\section{Determining places on hierarchies - the process of 'mapping'}

For the majority of the young people, who were involved in the research, this position relative to their friends and peers, was 'mapped' onto the hierarchy of HE courses and institutions that they (and their families) had constructed; this helped them to decide what, for them, constituted a 'feasible' choice.

As would, perhaps, be expected from the way in which the young people constructed their HE hierarchies and, in particular, the importance they assigned to the status of subjects vis-à-vis that of institutions, the impact of peer hierarchies on subject choice was most significant within Zoë and Charlotte's friendship group. Charlotte's HE choices can be seen as highly dependent on the way in which she transposed her 'rank' relative to her friends onto the hierarchy of degree subjects that she had constructed. I have argued above that the constant comparisons made by Charlotte and her friends had the effect of distorting their perception of their own academic ability (at least, compared to the actual results that the young women obtained). The great significance which was attached to relatively small differences in performance seemed to convince Charlotte that she was not 'clever enough' to read medicine (despite a strong, and clearly expressed, desire to study the subject when she began at Emily Davies College). Throughout the two years of their A Level studies, Zoë had identified strongly with becoming a doctor and, as Charlotte's grades were not quite as high as Zoë's, Charlotte seemed to assume that she was not as suited to a medical career as her friend. She thus chose to read law - a subject in keeping with her view of herself as part of a 'high achieving' friendship group, but one which also reflected her perception of her 'inferior' level of achievement when compared to Zoë.

Across the sample as a whole, the process of mapping was most apparent in decisions about institutions. Both Liz and Jim made a positive choice to apply to what they considered to be lower status institutions, primarily because of their beliefs about their own 'ability' relative to others. Despite advice from one of her teachers that she should apply to a university asking for A and B grades, Liz explained that:

Liz: I'd love to go to a low status college and feel one of the best instead of going to a high one and feeling really stupid. (Interview 3 )

Jim described his preferences in a similar way:

Jim:

Even if my target grades went up to all Cs, I wouldn't want to go somewhere like Southampton cos I'm not that intelligent and they're all like intelligent people that go to all the traditional ones and I would rather 
RB:

keep away from them.

Jim:

Why's that?

I don't know. I'd always feel like lower than them. I'd rather be with people of my own sort of level. (Interview 3)

Thus, he felt that even if his actual attainment was as high as that of other students, his ability or 'intelligence' would remain lower.

From these quotations, it is apparent that the HE decisions of both Liz and Jim were highly dependent on the way in which they perceived their academic ability relative to others. Both seemed to have a fixed and deeply embedded sense of their own 'ability', which was not amenable to change either as a result of an increase in their actual level of attainment or encouragement and reassurance from teachers. Neither Jim nor Liz rejected 'higher status' HE institutions on grounds of social discomfort (in contrast to many of the respondents in Reay et al.'s (2001b) research), but because of the way in which they positioned themselves academically - beneath many of their peers. Nevertheless, as I have argued above, Liz's sense of academic inferiority relative to others, and the mismatch between her own perception of her academic ability and the actual grades she received, seems to be explained by her social position and, in particular, her relative lack of cultural capital.

Becky also attempted to match her 'rank' with what she perceived to be an appropriate HEI. However, in contrast to the young people discussed above, she was concerned to identify high status institutions, requiring high A Level grades. Becky was acutely aware of her own position relative to the other members of her friendship group and she wanted to attend a university with other young people who had achieved similarly high grades:
RB:
You've mentioned high entry requirements a few times. Is that something that's very important to you in deciding where to apply?
Becky: Yeah, cos I think that if they've got such high entry requirements it shows that they are, you know, they've got high standards and I think it's just a reflection on sort of the teaching, and what the other students will be like. Everyone will be motivated towards working. It won't be like at school and college where everyone's across such a wide spectrum of ability that um...if you do work really hard it makes you stand out so much from everybody else. It makes you different from everybody else. I want to go somewhere where everyone is under the same sort of pressure and everyone does the same amount of work and everyone has the same mentality about doing their work. (Interview 3)

In contrast to Becky, Jim and Liz, most of the other young people in the research reached their decision about what constituted a feasible application for them by differentiating themselves from others both above and below them on the 'hierarchy of ability'. Steve's mapping process was typical of many:

I would imagine that you're looking at, with Joe, the top band of universities, then you're looking at like myself and Ben, you're looking at maybe a bit lower, but still good standard universities. It's a bit like a cascade, a waterfall down towards...I think Marco, who's doing the GNVQ....Y Yeah, I would imagine some of us will be going to different types of university entirely. (Interview 2) 
Several of the young people did not restrict themselves to mapping their own position onto these higher education hierarchies. Indeed, many were also clear about where they would locate their friends. In the extract above, for example, Steve made an explicit link between the ranking of individuals within his friendship group and the HEI to which he thought they would be likely to get in. He continued to make such comparisons throughout the two years of the research, even when his friends were about to begin their university courses:

I think Mark might have made a bit of a mistake going to Brunel cos I've a feeling.....he's going there to do American Studies...but I believe he got about the same [A Level grades] as me and...I'm sure he could have got somewhere a bit better than that to do American Studies cos that's like an engineering university - that's what it specialises in. (Interview 6)

\section{'Habitus' and the mapping process}

The research upon which this paper draws involved a relatively small number of young people and their friends. As a result, the tentative status of the findings discussed above should be emphasised. Nonetheless, it provides some insight into the different ways in which young people from broadly middle class backgrounds have engaged with the HE market and thus helps to fill what Power (2001) has described as the "empirical gap which has grown ever more glaring as the number of people deemed to be "middle class" grows and as the conventional indicators of success and failure shift upwards and become harder to define' (p.196-97).

In contrast to studies of the HE choices of young people from working class backgrounds (Hutchings and Archer, 2001; Reay et al., 2001b), amongst the Emily Davies students there was little evidence of distortion to the mapping process on the basis of social class. For example, no students talked about not wanting to attend any particular institution (other than Oxbridge) for reasons related to social discomfort. Comments which were frequently reported in Reay et al.'s (2001b) study, such as 'What's a person like me going to do at a place like that?' (p.864) were notably absent from the narratives of the young people involved in this research, other than in academic terms. However, this is not to deny the impact of class and various other social factors on the process of choice. The preceding sections of this paper have illustrated some of the specific ways in which the young people's HE choices were patterned by their social location. For example, the means by which they constructed their hierarchies of HEIs and courses, and the close correspondence between the views of the young people and their parents/step-parents, strongly supports Bourdieu's (1976) contention that:

Each family transmits to its children, indirectly rather than directly, a certain cultural capital and a certain ethos. The latter is a system of implicit and deeply interiorised values which, among other things, helps to define attitudes towards....educational institutions. (p.110)

However, this paper has also illustrated a number of social processes that do not seem to be adequately explained by Bourdieu's notion of a durable habitus, or the mechanisms of his theory of cultural reproduction. First, it appears that several of the social processes that distorted the relationship between the ranking of friends and their actual attainment cannot be explained on the basis of SES alone - and thus not in terms of Bourdieu's theorising. One obvious example of this is the way in which extreme levels of competitiveness within Charlotte and Zoë's group affected their sense of their own academic ability (and, as a result, their HE choices). Second, 
the differences between some of the young people from a similar social location may suggest ways in which the young people and their parents were actively attempting to change their habitus. There is clearly considerable debate about the extent to which Bourdieu's concept of habitus is able to account for radical change. Mahar et al., (1990) and May (1996), for example, emphasize the fluidity of habitus as an individual moves through different contexts. However, I concur with Jenkins (1992) that Bourdieu's insistence on its unreflexive nature and role in conditioning learning and social experience throughout life make it 'almost immune to major upset' (p.79). Although Bourdieu did acknowledge that at 'times of crisis', when an adjustment between objective and subjective structures may be needed, the habitus may have a transformative rather than a reproductive role, his writings contain no account of the actual ways in which habitus may develop or be transformed; emphasis remains primarily on its reproductive role.

In contrast, several families in this study seemed to have effected substantial intergenerational change. Amongst the sample, very few of the young people came from families with any experience of HE. Nonetheless, several had developed an acute understanding of status differences between HE institutions and courses, and this had underpinned their decisionmaking processes. For some, this had also led them to adopt specific strategies to maximise their chances of gaining entry to a high status institution or course (for example, Zoë worked in a nursing home, shadowed relevant professionals and attended a short course for students hoping to study medicine at university). Instead, I have suggested that some of these differences between the young people can be explained by the specific contexts in which their parents worked and/or their (self-) identification as 'high achievers' early on in their schooling. In many ways, this intergenerational discontinuity reflects Halsey et al.'s (1980) observations in relation to access to selective schooling in the mid twentieth century. They noted that parental experience of selective education and high levels of cultural capital were relatively unimportant in determining the likelihood of gaining entry to academic or technical training. In explaining these patterns, Bourdieu would undoubtedly have contended that:

The exceptional success of those few individuals who escape the collective fate of their class apparently justifies educational selection and gives credence to the myth of the school as a liberating force among those who have been eliminated, by giving the impression that success is exclusively a matter of gifts and work. (1976, p.116)

and, indeed, the enduring nature of social inequalities within the HE sector (Egerton and Halsey, 1993) would suggest that such 'transformations of habitus' are not commonplace. Nevertheless, it would seem that these are precisely the kind of changes that warrant further investigation if the social composition of universities and colleges is to be altered in any significant way.

\section{Acknowledgements:}

I would like to thank the fifteen students at Emily Davies College who gave up considerable amounts of time to talk to me, and the ESRC for funding the research upon which the paper is based (award number: R00429944049). I am also grateful to Sue Heath, Wendy Bottero and two anonymous referees for very helpful comments on an earlier version of this paper. 


\section{References:}

AINLEY, P. (1994) Degrees of Difference. Higher Education in the 1990s (London, Lawrence and Wishart).

ARCHER, L. and HUTCHINGS, M. (2000) 'Bettering Yourself?' Discourses of risk, cost and benefit in ethnically diverse, young working-class non-participants' constructions of higher education, British Journal of Sociology of Education, 21, 4, pp.553-574.

BALL, S.J. (1981) Beachside Comprehensive: a case study of secondary schooling (Cambridge, Cambridge University Press).

BALL, S.J. and VINCENT, C. (2001) New Class Relations in Education: the Strategies of the 'Fearful' Middle Classes, in: DEMAINE, J. (Ed) Sociology of Education Today (Basingstoke, Palgrave).

BALL, S.J., DAVIES, J., DAVID, M. and REAY, D. (2002) 'Classification' and 'Judgement': social class and the 'cognitive structures' of choice of Higher Education, British Journal of Sociology of Education, 23, 1, pp.51-72.

BECKER, H., GREER, B. and HUGHES, E. (1968) Making the Grade: the Academic Side of College Life (New York, John Wiley).

BOURDIEU, P. (1976) The school as a conservative force: scholastic and cultural inequalities, in: DALE, R., ESLAND, G. and MacDONALD, M. (Eds) Schooling and Capitalism: a sociological reader (London, Routledge and Kegan Paul with the Open University Press).

BOURDIEU, P. (1997) The Forms of Capital, in: HALSEY, A., LAUDER, H., BROWN, P. and WELLS, A. (Eds) Education. Culture, Economy, Society (Oxford, Oxford University Press).

BROWN, P. and SCASE, R. (1994) Higher Education and Corporate Realities (London, UCL Press).

CROMPTON, R. (1992) Patterns of Consciousness amongst the Middle Classes, in:

BURROWS, R. and MARSH, C. (Eds) Consumption and Class. Division and Change (London, Macmillan).

DAVID, M. with BALL, S.J., DAVIES, J. and REAY, D. (2001) Parental Involvement in Student Choices of Higher Education: Gender, Family and Social Class Issues in the Processes. Paper presented at British Educational Research Association annual conference, University of Leeds, September 2001.

EGERTON, M. and HALSEY, A.H. (1993) Trends by social class and gender in access to higher education in Britain, Oxford Review of Education, 19, 2, pp.183-196.

GERSHUNY, J. (1994) Post-industrial career structures in Britain, in: EPSING-ANDERSEN, G. (Ed) Changing Classes (London, Sage).

GEWIRTZ, S., BALL, S. and BOWE, R. (1995) Markets, Choice and Equity in Education (Buckingham, Open University Press). 
GILLBORN, D. and YOUDELL, D. (2001) The New IQism: Intelligence, 'Ability' and the Rationing of Education, in: DEMAINE, J. (Ed) Sociology of Education Today (Basingstoke, Palgrave).

GOLDTHORPE, J. (1982) On the service class, its formation and future, in: GIDDENS, A. and MACKENZIE, G. (Eds) Social Class and the Division of Labour (Cambridge, Cambridge University Press).

GOLDTHORPE, J. (1995) The service class revisited, in: BUTLER, T. and SAVAGE, M. (Eds) Social Change and the Middle Classes (London, UCL Press).

GOLDTHORPE, J. (1996) Class analysis and the reorientation of class theory: the case of persisting differentials in educational attainment, British Journal of Sociology, 47, 3, pp.481505 .

GOLDTHORPE, J. (1998) Rational action theory for sociology, British Journal of Sociology, 49, 2, pp.167-192.

HALSEY, A., HEATH, A. and RIDGE, J. (1980) Origins and Destinations. Family, Class and Education in Modern Britain (Oxford, Clarendon Press).

HARGREAVES, D. (1967) Social Relations in a Secondary School (London, Routledge and Kegan Paul).

HATCHER, R. (1998) Class differentiation in education: rational choices? British Journal of Sociology of Education, 19, 1, pp.5-24.

HINETT, K. (2002) Failing to assess or assessing failure? in: PEELO, M. and WAREHAM, T. (Eds) Failing Students in Higher Education (Buckingham, Society for Research into Higher Education and Open University Press).

HODKINSON, P., SPARKES, A. and HODKINSON, H. (1996) Triumphs and Tears: Young People, markets and the transition from school to work (London, David Fulton Publishers Ltd).

HUTCHINGS, M. and ARCHER, L. (2001) 'Higher than Einstein': constructions of going to university among working-class non-participants, Research Papers in Education, 16, 1, pp.6991.

JAMES, D. (2001) Making the Graduate: perspectives on Student Experience of Assessment in Higher Education, in: FILER, A. (Ed) Assessment: Social Practice and Social Product (London, Routledge).

JENKINS, R. (1992) Pierre Bourdieu (London, Routledge).

LAUDER, H. and HUGHES, D. (1999) Trading in Futures. Why Markets in Education Don't Work (Buckingham, Open University Press).

MAHAR, C., HARKER, R. and WILKES, C. (1990) The Basic Theoretical Position, in: HARKER, R., MAHAR, C. WILKES, C. (Eds) An Introduction to the Work of Pierre Bourdieu. The Practice of Theory (Basingstoke, Macmillan). 
MAY, T. (1996) Situating Social Theory (Buckingham, Open University Press).

POWER, S. (2001) Missing: A Sociology of Educating the Middle Classes, in: DEMAINE, J. (Ed) Sociology of Education Today (Basingstoke, Palgrave).

PUGSLEY, L. (1998) Throwing your brains at it: higher education, markets and choice, International Studies in Sociology of Education, 8, 1, pp.71-90.

REAY, D. (1998) Class Work (London, University College Press).

REAY, D., DAVID, M. and BALL, S. (2001a) Making a Difference?: Institutional Habituses and Higher Education Choice, Sociological Research Online, 5, $4<\mathrm{http}$ ://www.socresonline. org.uk/5/4/reay.html> (Accessed 5/4/01).

REAY, D., DAVIES, J., DAVID, M. and BALL, S. J. (2001b) Choices of Degree or Degrees of Choice? Class, 'Race' and the Higher Education Choice Process, Sociology, 35, 4, pp.855-874.

SAVAGE, M. (1995) Class analysis and social research, in: BUTLER, T. and SAVAGE, M. (Eds) Social Change and the Middle Classes (London, UCL Press).

SAVAGE, M., BARLOW, J., DICKENS, P. and FIELDING, T. (1992) Property, Bureaucracy and Culture. Middle-Class Formation in Contemporary Britain (London, Routledge).

TROYNA, B. (1991) Underachievers or Underrated? The Experience of Pupils of South Asian Origin in a Secondary School, British Educational Research Journal, 17, 4, pp.361-376.

WALKERDINE, V., LUCEY, H. and MELODY, J. (2001) Growing Up Girl: psychosocial explorations of gender and class (Basingstoke, Palgrave). 
Table I. Characteristics of the young people involved in the research - social class and level of parental education

\begin{tabular}{llll}
\hline Name & $\begin{array}{l}\text { Social class (based on } \\
\text { Registrar-General's } \\
\text { classification of } \\
\text { occupation) }\end{array}$ & $\begin{array}{l}\text { Highest qualification } \\
\text { obtained by mother }\end{array}$ & $\begin{array}{l}\text { Highest obtained by } \\
\text { father/step-father }\end{array}$ \\
\hline Becky & IIIN & O Levels & \\
Charlotte & II & O Levels & O Levels \\
Clare & IIIN & O Levels & Degree \\
Jenny & II & O Levels & BTEC \\
Jim & II & O Levels & O Levels \\
Liz & V & O Levels & BTEC \\
Lucy & II & None & O Levels \\
Mark & II & Certificate of Education & A Lene \\
Paul & I & Certificate of Education & Degree \\
Rich & I & Degree & Degree \\
Sarah & II & O Levels & A Levels \\
Simon & II & A Levels & A Levels \\
Steve & II & O Levels & O Levels \\
Sunita & II & O Levels & O Levels \\
Zoë & IIIN & A Levels & A Levels \\
\hline
\end{tabular}

\footnotetext{
${ }^{2}$ Based on parental occupation. Where the class of mother's and father's occupation differed, the higher one was used.
} 